\title{
Communicating Branches Between the Median and Ulnar Nerves. Proposal for Inclusion in Terminologia Anatomica
}

\author{
Ramos Comunicantes entre los Nervios Mediano y Ulnar. \\ Propuesta de Inclusión en Terminologia Anatomica
}

Riveros, A. ${ }^{1,2}$; Olave, E. ${ }^{2,3}$; Nicholson, C. ${ }^{4}$; Schorwer, K. ${ }^{5}$ \& Torres, H. ${ }^{1}$

RIVEROS, A.; OLAVE, E.; NICHOLSON, C.; SCHORWER, K. \& TORRES, H. Communicating branches between the median and ulnar nerves proposal for inclusion in Terminologia Anatomica. Int. J. Morphol., 37(3):1192-1196, 2019.

SUMMARY: The ulnar and median nerves are widely distributed, innervating the muscles of the forearm and hand. In the latter, it also registers the sensitivity of a significant part of the skin. A series of communicating branches (CB) is described on the path of these nerves, including: 1) the Martin-Gruber communicating branch, 2) the Marinacci communicating branch, 3) the Riché-Cannieu communicating branch and 4) the Berrettini communicating branch. The aim of this study was to establish a correct denomination of these CB, using Latin and eliminating the use of eponyms. The exploratory study included books on anatomy and scientific articles that detailed the anatomical aspects of these CB. To these were added the terms that these branches presented in the various anatomical lists and terminologies. Each term proposal was done in Latin, using the corresponding gender, number and case. The CB between the median and ulnar nerves are described in anatomy texts as well as a plethora of publications. The prevalence rates of the CB range between 1.7 and $94 \%$; however, their inclusion in the anatomical terminologies has been limited. Based on the description of these branches and the presence of some of them in the existing terminologies, a proposal was prepared in line with the indications of the Federative International Programme on Anatomical Terminologies (FIPAT): 1) Ramus comunicans cum nervo ulnari, 2) Ramus comunicans cum nervo mediano, 3) Ramus communicans cum ramo profundo nervi ulnaris y 4) Ramus communicans cum nervo digitali palmari communi. Considering that terminologies are dynamic linguistic corpora, it is important to analyze constantly the incorporation of new terms that are in harmony with the scientific findings. The incorporation of new structures must follow FIPAT guidelines and include the grammatical aspects of Latin.

KEY WORDS: Communicating branch; Martin-Gruber; Marinacci, Riché-Cannieu; Berretini, Terminologia anatomica.

\section{INTRODUCTION}

The study of the peripheral nervous system involves detailed knowledge of the distribution of nerves in the different areas of the body. The brachial plexus is a nerve network formed by the ventral ramus of the lower four cervical nerves and first thoracic nerve (C5, C6, C7, C8, and T1). Among the nerves that form this brachial plexus are the ulnar and median nerves, noted for their extensive trajectory that terminates in the hand. These two nerves are profusely distributed, innervating the muscles of the anterior compartment of the forearm, the 19 muscles of the hand and registering the general sensitivity of the palm of the hand through cutaneous branches. Although the trajectory and different branches that arise from these nerves are known, there is a large number of communicating branches (CB) that determine variations in the normal distribution of the nerves mentioned. In this context, four important communicating branches stand out that are traditionally known through use of eponyms: a) the Martin-Gruber communicating branch (MGCB), b) the Marinacci communicating branch (MC), c) the Riché-Cannieu communicating branch ( $\mathrm{RCCB}$ ) and $\mathrm{d}$ ) the Berrettini communicating branch (BCB).

The International Federation of Associations of Anatomists (IFAA), through its different bodies, or the International Anatomical Nomenclature Committee (IANC), which was replaced in 1989 by the Federative International Committee for Anatomical Terminology (FICAT) and which

\footnotetext{
${ }^{1}$ Departamento de Ciencias Morfológicas, Facultad de Medicina y Ciencia, Universidad San Sebastián, Lientur 1457, Concepción 4080871, Chile.

${ }^{2}$ Programa de Doctorado en Ciencias Morfológicas, Universidad de La Frontera, Temuco, Chile.

${ }^{3}$ Facultad de Medicina, Universidad de La Frontera, Temuco, Chile.

${ }^{4}$ Núcleo de Idiomas, Facultad de Estudios Interdisciplinarios, Universidad Mayor, Chile.

${ }^{5}$ Departamento de Anatomía normal y Medicina legal. Facultad de Medicina, Universidad de Concepción, Concepción, Chile.
} 
we now know as the Federative International Programme on Anatomical Terminologies (FIPAT), is committed to eponyms not being used to name anatomical structures, which is in contrast to the common use of eponyms in anatomy texts and scientific publications in clinical and surgical morphology (Federative International Programme on Anatomical Terminologies, 2008).

On this basis, the aim of this study was to establish a correct nomenclature for these $\mathrm{CB}$, using Latin and eliminating the use of eponyms. This nomenclature was based on their anatomical description and considered the possible terms that these branches present in the various lists and existing anatomical terminologies.

\section{MATERIAL AND METHOD}

A bibliographical review was conducted using an exploratory study that included anatomy books and anatomical terminology texts. To this were added scientific articles or online sources that described the anatomical aspects of MGCB, MC, RCCB and $\mathrm{BCB}$. Once the anatomical detail of these communicating branches was known, the next step was to present a proposal for naming each of these branches, writing it in Latin and correctly using the corresponding gender, number and case.

\section{RESULTS}

The neural communications between the median and ulnar nerves are described in both classic anatomy texts (Testut \& Latarjet, 1972; Tountas \& Bergman, 1993; Rouvière \& Delmas, 2005; Llusá et al., 2013) and a myriad of publications. Based on these descriptions, the anatomical aspects of these four $\mathrm{CB}$ are detailed in the following.

a) Martin-Gruber communicating branch: This communication that forms in the forearm was described by Swedish anatomist Martin in 1763 and complemented by Gruber in 1870 . It was described as the branch that emerges from the median nerve or anterior interosseous nerve (branch of the median nerve) and moves towards the ulnar nerve, containing fibers dedicated to the intrinsic musculature of the hand. This allows the ulnar nerve to connect with the innervation of the two heads of the flexor pollicis brevis and/or adductor pollicis muscle (Fig. 1, A) (Rodriguez-Niedenführ et al., 2002; Wynter \& Dissanbandara, 2017; Riveros et al., 2018; Diz-Díaz et al., 2019). Its prevalence rate varies between 6 and $47.3 \%$, depending on whether the reports were obtained from cadaver samples or through electrophysiological studies (Roy et al., 2016).

b) Marinacci communicating branch: Described in 1964, this branch emerges from the ulnar nerve in the proximal region of the forearm to enter the epineurium of the median nerve in the medial or distal region of the forearm. Although its prevalence rate does not exceed $1.7 \%$, its presence alters the innervation of the forearm musculature and in particular the muscles of the hand (Fig. 1, B) (Roy et al.).

c) Riché-Cannieu communicating branch: Described in 1896, this branch establishes communication between the recurrent thenar motor branch of the median nerve and the deep branch of the ulnar nerve. Its variability is associated with the possibility of communicating the muscular branches that emerge from the recurrent thenar motor branch with the muscular branches that the deep branch of the ulnar nerve provides to the oblique and transverse heads of the adductor pollicis muscle. The prevalence rate reported for this branch is variable, reaching $79.1 \%$ of the population (Fig. 2, A) (Wolf-Heidegger, 1962; Roy et al.; Wynter \& Dissanbandara; Caetano et al., 2018).

d) Berrettini communicating branch: This communication, illustrated by Paolo Berrettini in 1741, has a prevalence that can reach $94 \%$, which means it may be considered an anatomical normality. It is described how to the neural connection between the common palmar digital nerves which originate in the median and ulnar nerves (Fig. 2, B) (Olave et al., 1998; Roy et al.; Wynter \& Dissanbandara).

In addition, and with respect to the inclusion of these communicating branches in the various anatomical lists or terminologies, the following were analyzed: a) the Basle Nomina Anatomica (His, 1895), b) the International Terminologia Anatomica, 2001, published by the IFAA and the Spanish Anatomical Society, translated into Spanish, c) Terminologia Neuroanatomica, proposed by the FIPAT, which is awaiting approval at the next IFAA conference, and d) Terminologia Anatomica proposed by the International Federation of Societies for Surgery of the Hand (2001). This is summarized in Table I.

Once the anatomical detail of these communicating branches and the presence of some of them in the existing terminologies had been analyzed, the next step was to construct the proposal in line with FIPAT guidelines. Table II summarizes the proposal by Kachlik et al. (2017), to which is added our terminological proposal for each communicating branch described. 


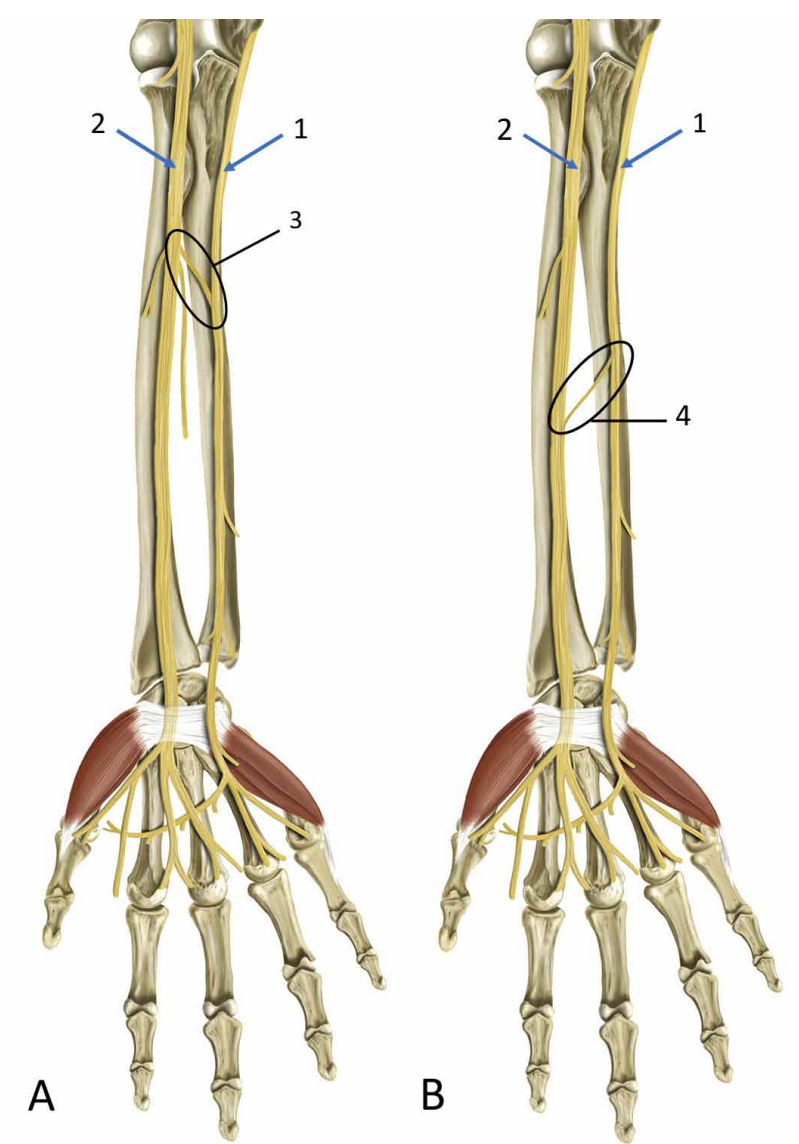

Fig. 1. Communicating branches between median and ulnar nerves in the forearm. Anterior view, right forearm. 1. Ulnar nerve; 2. Median nerve; 3: Martin-Gruber communicating branch; 4. Marinacci communicating branch.

\section{DISCUSSION}

Since the creation of the Basle Nomina Anatomica (BNA) (His), modern anatomists have persevered in the nomenclature of anatomical terms fulfilling four main principles: a) universality, b) respect for the Latin name, c) description of the anatomical element most faithful to the geometry and shape, and d) that the term is consistent with its derivatives (Cruz Gutiérrez et al., 2010; Vargas et al., 2016). This is faithfully reflected in its list of terms, as they were written in Latin, a situation that persisted in the modification of the Nomina Anatomica in 1955, known as the Paris Nomina Anatomica (PNA), and which after six updates was translated into the Terminologia Anatomica, approved by the IFAA in 1989 and is still in force today (Losardo et al., 2015). To this are added the functions of the FIPAT, where it is established that the names of the structures must have an informative value, that the adopted terms concentrate the greatest amount of information about and description of the structure, thereby avoiding the use of eponyms, i.e., an anatomical detail using a person's name (Villarroel et al., 2016). These same tasks are performed in the various Ibero-Latin American Symposia on Anatomical, Histological and Embryological Terminology (SILAT), which under the sponsorship of the Pan American Association of Anatomy (APA) analyzes and suggests corrections of the terms included in Terminologia Anatomica, Histologica y Embriologica (Cruz Gutiérrez et al.).

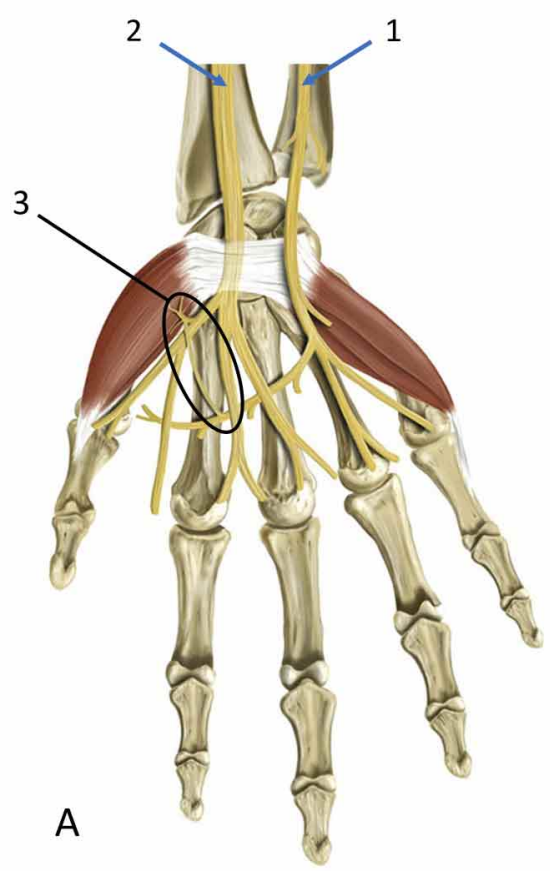

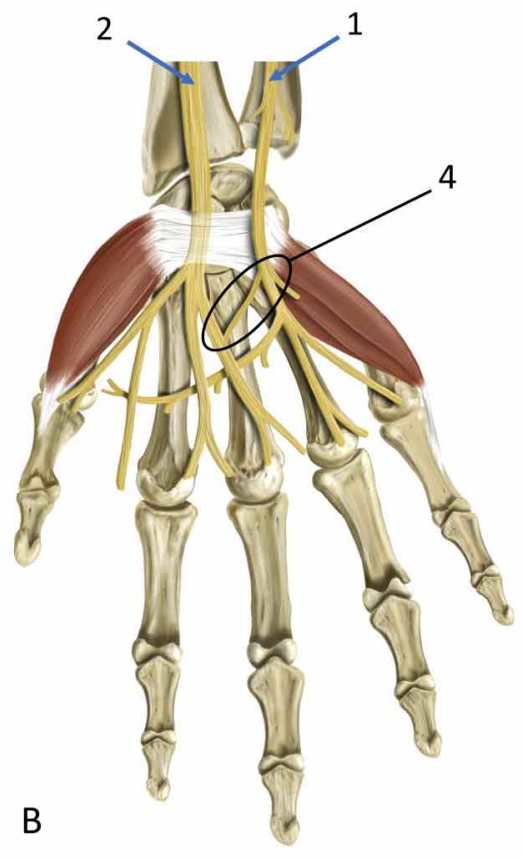

Fig. 2. Communicating branches between median and ulnar nerves in the hand. Anterior view, right hand. 1 . Ulnar nerve; 2 . Median nerve; 3 . Riche-Cannieu communicating branch; 4. Berretini communicating branch. 
RIVEROS, A.; OLAVE, E.; NICHOLSON, C.; SCHORWER, K. \& TORRES, H. Communicating branches between the median and ulnar nerves proposal for inclusion in Terminologia Anatomica Int. J. Morphol., 37(3):1192-1196, 2019

Table I. Denomination of the communicating branches between medium and ulnar nerves in the various terminologies.

\begin{tabular}{|c|c|c|c|c|c|}
\hline $\begin{array}{l}\text { Communicanting branche } \\
\text { (eponymous) }\end{array}$ & $\begin{array}{l}\text { Percentage of } \\
\text { Prevalence }\end{array}$ & $\begin{array}{c}\text { Basle Nomina anatomica } \\
\text { (1895) IFAA }\end{array}$ & $\begin{array}{l}\text { Terminologia anatomica } \\
\text { (2001) FICAT }\end{array}$ & $\begin{array}{c}\text { Terminologia neuroanatomica } \\
\text { (2017) FIPAT }\end{array}$ & Terminologia anatomica IFSSH \\
\hline Martin- Gruber & 19,5 & $\begin{array}{c}\text { Ramus anastomoticus cum } \\
\text { n. ulnari }\end{array}$ & $\begin{array}{c}\text { R. comunicans cum nervo } \\
\text { ulnari }\end{array}$ & Ramus comunicans ulnaris & $\begin{array}{l}\text { Ramus comunicans cum nervo } \\
\text { mediano (Martin-Gruber) }\end{array}$ \\
\hline Marinacci & 0,7 & not described & not described & not described & not described \\
\hline Riche-Cannieu & 55,5 & not described & not described & not described & $\begin{array}{l}\text { Ramus comunicans cum n. } \\
\text { ulnari (Riche-Cannieu) }\end{array}$ \\
\hline Berretini & 60,9 & not described & not described & not described & not described \\
\hline
\end{tabular}

Table II. Proposal of denomination of communicating branches between medium and ulnar nerves.

\begin{tabular}{lll}
\hline Communicanting & Proposal Kachlik et al., 2017 & Proposal Riveros et al. \\
\hline Martin- Gruber & Ramus communicans ulnaris nervi mediani & Ramus communicans cum nervo ulnari \\
Marinacci & Ramus communicans medianus nervi ulnaris & Ramus communicans cum nervo mediano \\
Riche-Cannieu & Ramus communicans thenaricus nervi ulnaris & Ramus communicans cum ramo profundo nervi ulnaris \\
Berretini & Ramus communicans digitalis nervi mediani & Ramus communicans cum nervo digitali palmari communi \\
\hline
\end{tabular}

In this vein, for Kachlik et al. (2015) the anatomical terminologies and nomenclatures in general are the main means of communication in the scientific fields and they must therefore be concise and consistent. However, Gest (2014) suggested that the use of eponyms is a show of respect for the historical development of the sciences, citing the example in the area of the physics, where Newton's laws, Bernoulli's principle or Laplace's law, among others, continue to be analyzed. Duque Parra et al. (2002), by contrast, is opposed, asserting that eponyms have no descriptive or informational value, added to which is a series of reports that insist on the use of the different eponyms in the different health professions as well as in morphological studies (Duque Parra et al.). Also, prior to the creation of an anatomical term, the name must encompass the descriptive information of the element at issue and contribute keys in the location of the term to be recognized, a situation reflected in the proposal for the four communicating branches.

In relation to the historical analysis of the naming of these branches, the BNA only incorporates the term Ramus anastomoticus cum n. ulnari, with reference to the MGCB; however, it uses the word anastomosis, which is reserved only for the joining of hollow structures (vessels, tubes). To be correct, when referring to the connections between nerves, the term ramus communicans is used (Kachlik et al., 2017). As illustrated in Table I, the term anastomosis was eliminated in the Terminologia Anatomica, being replaced by $R$. comunicans cum nervo ulnari (A14.2.03.037), correctly using the Latin grammar, since the term must be written in the masculine, singular and using the ablative case, which it seems to us is the ideal to refer to one anatomical structure being connected to another. It would also be incorrect to establish this branch as Ramus comunicans ulnaris, as suggested by the Terminologia Neuroanatomica, which uses the genitive case (Federative International Programme on Anatomical Terminologies, 2017). Unfortunately, the name used by the International Federation of Societies for Surgery of the Hand
(IFSSH) lacks an anatomical foundation since for them, Ramus comunicans cum nervo mediano (Martin-Gruber) is the one joining the ulnar nerve to the median nerve, which is called the Marinacci communication. At the same time, Ramus comunicans cum n. ulnari (Riché-Cannieu) is associated with the branch that goes from the median nerve to the ulnar nerve, without contributing any details on the specific branches that are communicated by this neural connection.

With regard to our proposal, we consider it important that the these names be expressed in the masculine, singular and the ablative case, which is in contrast to that expressed by Kachlik et al. (2017), where these names are expressed using the genitive. In this sense, when analyzing the Terminologia Anatomica we found that 14 terms that referred to $R$. Communicans are named using the ablative case. These terms include $R$. Communicans cum nervo zygomatico (A14.2.01.019), R. Communicans cum ganglio ciliari (A14.2.01.026) and R. Communicans cum nervo vago (A14.2.01.120) (Comité Federal sobre Terminología Anatómica \& Sociedad Anatómica Española, 2001).

Finally, and drawing on the prevalence of each of these communicating branches, it is important to note that the Terminologia Anatomica includes 149 structures that are considered anatomical variants, which are cited in parentheses to differentiate them. For Kachlik et al. (2015), this selection should be broadened and refined; these structures should even form a separate list. On this basis, we consider Ramus comunicans cum nervus mediano to be framed in the concept of a variation, a situation that for the case of Ramus comunicans cum nervus ulnari must be discussed in depth. For the cases of the Ramus communicans cum ramo profundo nervi ulnaris and the Ramus communicans cum nervo digitali palmari communi, the prevalence rates exceed $50 \%$, which could substantiate their incorporation in the Terminologia Anatomica as branches that present normally and not as an anatomical variation. 
In conclusion and considering that terminologies are dynamic linguistic corpora, it is important to constantly analyze the incorporation of new terms that are in harmony with the scientific morphological findings. The incorporation of new structures must follow FIPAT - IFAA guidelines and include the various grammatical aspects of Latin.

ACKNOWLEDGEMENTS. We wish to thank the illustrator, Mr. Alfredo Torres Parra, for his pictorial contribution to this paper.

RIVEROS, A.; OLAVE, E.; NICHOLSON, C.; SCHORWER, K. \& TORRES, H. Ramos comunicantes entre los nervios mediano y ulnar. Propuesta de inclusión en Terminologia Anatomica. Int. J. Morphol., 37(3):1192-1196, 2019.

RESUMEN: Los nervios ulnar y mediano presentan una amplia distribución que permite inervar músculos del antebrazo y mano, en esta última, también registran la sensibilidad de un importante territorio cutáneo. En el recorrido de estos nervios se describen una serie de ramos comunicantes (RC), entre los cuales destacan: 1) Ramo comunicante de Martin-Gruber 2) Ramo comunicante de Marinacci 3)Ramo comunicante de Riché-Cannieu y 4) Ramo comunicante de Berretini. El propósito de este trabajo fue establecer una correcta denominación de estos RC, usando para ello el latín y eliminando el uso de epónimos. El estudio exploratorio incluyó libros de anatomía y artículos científicos que detallaran los aspectos anatómicos de estos RC. A lo anterior se sumaron los términos que estos ramos presentaron en las diversas nóminas y terminologías anatómicas. Cada propuesta de denominación se realizó en latín, utilizando el género, número y caso correspondiente. Los RC entre los nervios mediano y ulnar se encuentran descritos tanto en textos de anatomía como en un sinnúmero de publicaciones. Las tasas de prevalencia de los RC fluctúan entre 1,7 y $94 \%$; a pesar de ello; su inclusión en las terminologías anatómicas ha sido limitado. En base a la descripción de éstos ramos y la presencia de algunos de ellos en las terminologías existentes, se elaboró una propuesta alineada con las indicaciones del Programa Federativo Internacional de Terminología Anatómica (FIPAT): 1) Ramus comunicans cum nervo ulnari, 2) Ramus comunicans cum nervo mediano, 3) Ramus communicans cum ramo profundo nervi ulnaris y 4) Ramus communicans cum nervo digitali palmari communi. Considerando que las terminologías son cuerpos lingüísticos dinámicos, resulta importante analizar constantemente la incorporación de nuevos términos que se encuentren en sintonía con los hallazgos científicos. La incorporación de nuevas estructuras debe seguir los lineamientos de FIPAT y considerar los aspectos gramaticales del latín.

PALABRAS CLAVE: Ramo comunicante; Martin-Gruber; Marinacci; Riché-Cannieu; Berretini, Terminologia Anatomica.

\section{REFERENCES}

Caetano, E. B.; Vieira, L. A.; Nakamichi, Y. C.; Sawada, M. M.; de Andrade, R. A. \& Nakasone, M. T. Anastomosis between the deep branch of ulnar nerve and a branch of the median nerve (Cannieu-Riché anastomosis) and thenar muscles innervation. Anatomical study and clinical implications. Int. J. Morphol., 36(1):7-13, 2018.

Comité Federal sobre Terminología Anatómica \& Sociedad Anatómica Española. Terminología Anatómica. Terminología Anatómica Internacional. Buenos Aires, Médica Panamericana, 2001.
Cruz Gutiérrez, R.; Rodríguez Torres, A.; Prates, J. C.; Losardo, R. J. \& Barbato, N. V. Ibero-Latin-American Symposia Terminology. Anatomy, Histology and Embryology. Int. J. Morphol., 28(1):333-6, 2010.

Diz-Díaz, J.; Gómez-Muñoz, E.; Sañudo, J.; Maranillo, E.; Pascual-Font, A. \& Vazquez, T. Which is the function of a Martin-Gruber connection? Clin. Anat., 32(4):501-8, 2019.

Duque Parra, J. E.; Gomez Arias, N. C. \& Giraldo Rios, D. P. Nomenclatura anatomica internacional: ¿Un horno microondas en el interior de un volcan activo?. Med. U. P. B., 21(1):43-55, 2002.

Federative International Programme on Anatomical Terminologies (FIPAT) Terminologia Anatomica. International Anatomical Terminology. Stuttgart, Georg Thieme Verlag, 2008.

Federative International Programme on Anatomical Terminologies (FIPAT). Terminologia Neuroanatomica. International Neuroanatomical Terminology. Halifax, Dalhousie University Libraries, 2017. Available from: http:// fipat.library.dal.ca/TNA/

Gest, T. R. Anatomical nomenclature and the use of eponyms. Clin. Anat., 27(8):1141, 2014.

His, W. Nomina Anatomica. Leipzig, Verlag von Veit \& Comp., 1895.

International Federation of Societies for Surgery of the Hand (IFSSH) Terminology for Hand Surgery. Londres, Harcourt Health Science, 2001.

Kachlik, D.; Musil, V. \& Baca, V. Contribution to the anatomical nomenclature concerning upper limb anatomy. Surg. Radiol. Anat., 39(4):405-17, 2017.

Kachlik, D.; Musil, V. \& Baca, V. Terminologia Anatomica after 17 years: inconsistencies, mistakes and new proposals. Ann. Anat., 201:8-16. 2015.

Llusá, M.; Palazzi, S. \& Valer, A. Anatomía Quirúrgica del Plexo Braquial y de los Nervios Periféricos de la Extremidad Superior. Buenos Aires, Médica Panamericana, 2013.

Losardo, R. J.; Prates, N. E. V. B.; Arteaga-Martínez, M.; Haltí-Cabral, R. \& García-Peláez, M. I. International Morphological Terminology: more than Anatomy, Histology and Embryology. Int. J. Morphol., 33(1):400-7, 2015.

Olave, E.; del Sol, M. \& Gabrielli, C. Disposition and relationships of the communicating branch between the unlar and median nerves in the human hand. Rev. Chil. Anat., 16(2):263-9, 1998.

Riveros, A.; Olave, E. \& Sousa-Rodrigues, C. Anterior interosseous nerve: course, distribution and clinical implications. Int. J. Morphol., 36(3):1079-86, 2018.

Rodriguez-Niedenführ, M.; Vazquez, T.; Parkin, I.; Logan, B. \& Sañudo, J. R. Martin-Gruber anastomosis revisited. Clin. Anat., 15(2):129-34, 2002

Rouvière, H. \& Delmas, A. Anatomía Humana. Descriptiva, Topográfica y Funcional. Vol. 3. 11 $1^{\text {a }}$ ed. Madrid, Masson, 2005.

Roy, J.; Henry, B. M.; Pekala, P. A.; Vikse, J.; Saganiak, K.; Walocha, J. A. \& Tomaszewski, K. A. Median and ulnar nerve anastomoses in the upper limb: A meta-analysis. Muscle Nerve, 54(1):36-47, 2016.

Testut, L. \& Latarjet, A. Tratado de Anatomía Humana. Vol. 3. $9^{a}$ ed. Barcelona, Salvat, 1972.

Tountas, C. P. \& Bergman, R. A. Anatomics Variations of the Upper Extremity. Londres, Churchill Livingstone, 1993.

Vargas, C. A.; Ottone, N. E.; Contreras, M. \& del Sol, M. Facies or Impressio in the Spleen? Int. J. Morphol., 34(3):1002-8, 2016.

Villarroel, G. M.; Acuña, S. C.; Olguín, A. C. \& Velásquez, S. F. Deltoid tubercle: discrepancies between the anatomical terminology and anatomical bibliography. Int. J. Morphol., 34(4):1318-21, 2016.

Wolf-Heidegger, G. Atlas de Anatomia Humana. Vol. 3. Rio de Janeiro, Guanabara Koogan, 1962.

Wynter, S \& Dissabandara, L. A comprehensive review of motor innervation of the hand: variations and clinical significance. Surg. Radiol. Anat., 40(3):25969, 2017.

Corresponding author:

Klgo. Mg. Andrés Riveros Valdes

Depto. de Ciencias Morfológicas

Universidad San Sebastián - Sede Concepción

Lientur 1457

Concepción - CHILE

Email: andres.riveros@uss.cl

Recibido : 21-02-2019

Aceptado: 11-04-2019 